\title{
Influence of Graded Levels of Niacin on in vitro Digestibility of Total Mixed Ration with Different Non-Protein Sources
}

\author{
Tejbeer Singh $^{1^{*}}$, J.S. Lamba ${ }^{2}$, R.S. Grewal ${ }^{2}$ and M. Javed ${ }^{3}$ \\ ${ }^{1}$ Krishi Vigyan Kendra, Langroya, Shaheed Bhagat Singh Nagar, India \\ ${ }^{2}$ Department of Animal Nutrition, College of Veterinary Science, Guru Angad Dev Veterinary \\ and Animal Science University, Ludhiana, Punjab, India \\ ${ }^{3}$ Department of Math, Stat and Physics P.A.U., Ludhiana, Punjab, India
}

*Corresponding author

\section{A B S T R A C T}

\begin{tabular}{l} 
K e y w o r d s \\
$\begin{array}{l}\text { In vitro gas production, } \\
\text { Niacin, Slow release } \\
\text { urea, Total mixed } \\
\text { ration, Urea, Uromol }\end{array}$ \\
Article Info \\
\hline $\begin{array}{l}\text { Accepted: } \\
10 \text { March } 2018 \\
\text { Available Online: } \\
10 \text { April } 2018\end{array}$ \\
\hline
\end{tabular}

Keywords

Niacin, Slow release

ration, Urea, Uromo

\section{Article Info}

Accepted:

Available Online:

10 April 2018
The present study was undertaken to analyze the influence of graded levels of niacin supplementation $(0,200,400$ and $600 \mathrm{ppm}$, respectively) by in vitro gas production technique. The non-protein nitrogen sources were replaced by $30 \%$ of total crude protein of total mixed ration. It was found that true digestibility, organic matter digestibility and microbial mass production were significantly comparable in slow release urea and uromol based total mixed ration. Supplementation of niacin in urea $(30 \%)$ based total mixed ration do not have any significant effect on microbial mass production and its efficiency. The in vitro ammonia concentration was significantly reduced at $600 \mathrm{ppm}$ level of niacin supplementation. The total volatile fatty acid concentration was significantly higher at $200 \mathrm{ppm}$ level and lower at 400ppm level of niacin supplementation. Thus from the above study, it can be concluded that slow release urea give better result as compared to urea and uromol as non-protein nitrogen sources supplement in the diets of ruminants when replaced with $30 \%$ of total crude protein.

\section{Introduction}

Niacin is a water-soluble B-vitamin synthesized by rumen microorganisms. Structurally niacin consists of a pyrimidine ring having either an amide or carboxylic acid side group at position 5. Based on side groups, niacin consists of two forms: nicotinamide (NAM) and nicotinic acid (NA). NAM is more reactive form as compared to NA. Both NAM and NA incorporated into an essential coenzyme called nicotinamide adenine dinucleotide (NAD). NAD is the key enzyme in many oxidation reactions involved in energy metabolism. Niacin required in mitochondria respiration, metabolism of carbohydrate, lipids and amino acids. Ruminants get niacin from feedstuffs which can be formed from enzymatic conversion of tryptophan and also from microbial protein synthesis. Niacin present in feedstuffs in bound form due to which it becomes unavailable to the ruminants. Thus formation of niacin from tryptophan is ineffective. Also $50-60 \mathrm{mg}$ of tryptophan is needed for production of $1 \mathrm{mg}$ of niacin (Dreosti, 1984). 
Very little niacin is produced by microbial protein synthesis which is not sufficient to meet the requirements of calves and high producing dairy cows in early lactation (Campbell et al., 1994). Plant and animal proteins are best protein sources of niacin to be used but they are very uneconomical due to high cost. Non protein nitrogen (NPN) sources are most commonly used as protein supplements. They have high nitrogen density, low cost per unit nitrogen and ruminants have the ability to utilize nitrogen. Niacin play an important role in various biological oxidation, carbohydrate, protein and lipid metabolism which are important in the metabolic reactions that furnish energy to the animal (Erickson et al., 1990). Hence this study was undertaken to see the effect of graded levels of niacin supplementation on nitrogen utilization from different NPN sources in total mixed rations (TMR) by in vitro gas production analysis.

\section{Materials and Methods}

\section{Animal feeding and rumen analysis}

Rumen liquor was collected in morning (6 am) from fistulated animals before feeding and watering into a pre-warmed thermo-flask and brought to the laboratory. Donor animals were fed on basal diet (concentrate @ $3 \mathrm{~kg}$ and wheat straw ad libitum).

The in vitro gas production was done according to Menke et al., (1979). The amount of net gas produced (NGP) was used to calculate the metabolizable energy (ME) value. Neutral Detergent Fibre (NDF) of the residue was also determined. Total degradable sample (TDS), organic matter degradability (\% OMD), partition factor (PF), organic matter degradability (\% OMD), neutral detergent fiber degradability (\% NDFD), microbial biomass production (mg, MBP), efficiency of microbial mass production (\% EMMP), true digestibility (\% TD) and short chain fatty acids (mmol, SCFA) were calculated according to Makkar (2004). Volatile fatty acids (VFAs) were estimated by (Cottoyn and Boucque, 1968) using gas liquid chromatography (GLC) technique using Net Chrom-9100 model. The gas column (6 ft length and 1/8 inch diameter) packed with chromosorb 101 was used for the estimation of VFA. The gas flow for nitrogen hydrogen and zero air were 30,30, and $320 \mu \mathrm{l} / \mathrm{min}$, respectively. Temperature of injector oven, column oven and detector were $270^{\circ} \mathrm{C}, 172^{\circ} \mathrm{C}$ respectively.

\section{Statistical analysis}

Data found from in vitro study were analyzed $1 \times 3 \times 4$ factorial design (Snedecor and Cochran, 1994), by using SPSS Version 19. The differences in means were tested by Tukey B.

\section{Results and Discussion}

The chemical composition of different total mixed rations containing control, urea, uromol and slow release urea with graded levels of niacin is shown in Table 1.

The effect of different NPN sources, irrespective of niacin levelswith $30 \%$ replacement of total crude protein $(\mathrm{CP})$ of TMR in 60: 40 (Roughage: Concentrate) ratios was studied on in vitro utilization of nutrients is shown in Table 2.

The net gas production was significantly lower in slow release urea $(80.88 \mathrm{ml})$ and uromol based TMR $(80.63 \mathrm{ml})$ and significantly higher in control TMR. There was no significant effect seen on amount of truly degraded substrate (TDS) in all different NPN sources TMR as well as in control TMR.

The partitioning factor (PF) is the ratio of organic matter degraded (mg) in vitro to the 
volume of gas (ml) produced. In this study, PF values were significantly lower in urea (2.97) and control based TMR (3.17) and higher PF value was observed in slow release urea based TMR (3.42). The OMD \% was significantly lowest in urea $(74.53 \%)$ and uromol based rations $(76.01 \%)$ and significantly higher in slow release urea based rations (81.98\%), whereas a significant effect has been seen on NDFD \%. It was observed to be lowest in urea $(49.49 \%)$ and control (52.02\%) TMR and statistically comparable in uromol and slow release urea based TMR. Microbial mass production was statistically comparable in slow release urea and uromol based rations, but it was significantly lowest in control TMR (139.62 mg). Efficiency of microbial mass production (62.24\%) was significantly higher in TMR containing uromol as NPN source and lowest in control TMR. Metabolizable energy (ME) was significantly lower in slow release urea based TMR (9.11 MJ/kg DM) and higher in control TMR (10.51 MJ/kg DM). The short chain fatty acids (SCFA) were significantly lower in uromol $(1.79 \mathrm{mmol})$ and slow release urea based $(1.78 \mathrm{mmol})$ rations and significantly higher in control $(2.01 \mathrm{mmol})$. The concentration of ammonia was significantly lower in control total mixed ration $(22.35 \mathrm{mg} / \mathrm{dL})$ and higher in uromol based TMR (26.59 mg/dL).

The amount of fermentable methane was significantly lowest $(0.337 \mathrm{mmol})$ in urea based TMR and highest in slow release urea based TMR (0.346 mmol).The fermentable carbon dioxide was significantly lower $(0.52$ mmol) in TMR having uromol TMR and significantly higher in urea based TMR (0.54 mmol).

Effect of niacin supplementation at graded levels in TMR having 60: 40 (roughage: concentrate) replacing $30 \%$ of total protein, irrespective of NPN sources on in vitro utilization of nutrients is presented in Table 3 .
Niacin supplementation at graded levels has no significant effect on in-vitro digestibility parameters like NGP (ml), PF and OMD (\%). There was significant effect on NDFD \% which was lowest at $0 \mathrm{ppm}$ and $200 \mathrm{ppm}$ levels of niacin and highest at $600 \mathrm{ppm}$ level of niacin supplemented TMR. The microbial mass production was theoretically higher at $600 \mathrm{ppm}$ level of niacin supplementation although the results have no significant effect. The ME values varied from $9.45 \mathrm{MJ} / \mathrm{kg} \mathrm{DM}$ (0ppm) and $9.46 \mathrm{MJ} / \mathrm{kg}$ DM (200 ppm) showing no significant effect on different levels of niacin supplementation. There was no significant change in $\mathrm{pH}$ was observed with different levels of niacin supplementation in TMR.

The concentration of ammonia was decreased with at $600 \mathrm{ppm}$ level $(21.74 \mathrm{mg} / \mathrm{dL})$ and increased at $0 \mathrm{ppm}$ level $(26.58 \mathrm{mg} / \mathrm{dL})$ of niacin supplementation in TMR. Similarly lower ammonical nitrogen concentration was reported earlier in cattle (Riddell et al., 1980, 1981; Horner et al., 1988) and buffaloes (Nangia et al., 2000) that received supplemental niacin in their diet. The fermentable methane (mmol) was significantly higher at $0 \mathrm{ppm}$ level $(0.344 \mathrm{mmol})$ followed by $200 \mathrm{ppm}, 400 \mathrm{ppm}$ and lowest at $600 \mathrm{ppm}$ level of niacin supplementation $(0.341 \mathrm{mmol})$ in TMR. The fermentable $\mathrm{CO}_{2}$ was significantly lowest at $0 \mathrm{ppm}$ level $(0.532 \mathrm{mmol})$ and highest at $200 \mathrm{ppm}$ level of niacin supplemented TMR $(0.534 \mathrm{mmol})$.

The effect of different NPN sources, irrespective of niacin levels and level of replacement on total and individual volatile fatty acids is presented in (Table 4). The TVFA was significantly lowest in uromol based TMR (4.93 $\mathrm{mmol} / \mathrm{dL})$ and was significantly higher in urea based TMR (6.44 $\mathrm{mmol} / \mathrm{dL}$ ). The relative percent of acetate was significantly lowest $(66.82 \%)$ in uromol and highest in urea based TMR (69.51\%). 
Table.1 Chemical composition of total mixed rations with different NPN sources, \%DM basis

\begin{tabular}{|c|c|c|c|c|c|c|c|c|c|c|c|c|c|c|c|c|}
\hline \multirow{3}{*}{$\begin{array}{c}\text { PARAMETERS } \\
\%\end{array}$} & \multicolumn{4}{|c|}{ Control } & \multicolumn{4}{|c|}{ Urea $(30 \%)$} & \multicolumn{4}{|c|}{ Uromol $(30 \%)$} & \multicolumn{4}{|c|}{ Slow releasing urea $(30 \%)$} \\
\hline & \multicolumn{4}{|c|}{ Level of niacin (ppm) } & \multicolumn{4}{|c|}{ Level of niacin (ppm) } & \multicolumn{4}{|c|}{ Level of niacin (ppm) } & \multicolumn{4}{|c|}{ Level of niacin (ppm) } \\
\hline & 0 & 200 & 400 & 600 & 0 & 200 & 400 & 600 & 0 & 200 & 400 & 600 & 0 & 200 & 400 & 600 \\
\hline $\mathbf{C P}$ & 14.63 & 14.60 & 14.70 & 14.47 & 14.75 & 14.65 & 14.80 & 14.85 & 14.64 & 14.56 & 14.60 & 14.68 & 14.8 & 14.7 & 14.62 & 14.67 \\
\hline ASH & 6.60 & 6.67 & 6.77 & 6.75 & 6.40 & 6.40 & 6.60 & 6.80 & 7.20 & 7.17 & 7.20 & 7.20 & 7.2 & 7.25 & 7.50 & 7.35 \\
\hline OM & 93.40 & 93.32 & 93.22 & 93.25 & 93.60 & 93.60 & 93.40 & 93.20 & 92.80 & 92.82 & 92.80 & 92.80 & 92.80 & 92.75 & 92.50 & 92.65 \\
\hline NDF & 37.50 & 37.20 & 37.40 & 37.90 & 48.70 & 48.40 & 47.85 & 48.60 & 38.6 & 38.8 & 38.90 & 38.8 & 48.70 & 49.30 & 49.0 & 48.80 \\
\hline ADF & 23.40 & 23.80 & 23.60 & 23.90 & 23.20 & 22.70 & 22.95 & 22.95 & 20.7 & 20.5 & 20.4 & 20.6 & 22.95 & 23.00 & 22.25 & 22.25 \\
\hline $\mathrm{HC}$ & 14.10 & 13.40 & 13.80 & 14.00 & 25.50 & 25.70 & 24.90 & 25.65 & 17.9 & 18.3 & 18.55 & 18.20 & 25.75 & 26.30 & 26.75 & 26.55 \\
\hline FAT & 3.10 & 3.15 & 2.93 & 3.05 & 2.60 & 2.72 & 2.90 & 2.75 & 2.57 & 2.57 & 2.8 & 2.56 & 2.55 & 2.57 & 2.50 & 2.50 \\
\hline CELLULOSE & 13.60 & 13.80 & 13.40 & 13.20 & 18.55 & 18.80 & 18.75 & 18.80 & 14.10 & 14.15 & 14.30 & 14.60 & 17.20 & 16.95 & 16.80 & 17.05 \\
\hline T CHO & 75.67 & 75.57 & 75.59 & 75.72 & 76.24 & 76.22 & 75.70 & 75.59 & 75.59 & 75.69 & 75.40 & 75.56 & 75.45 & 75.47 & 75.38 & 75.48 \\
\hline NFC & 38.17 & 38.37 & 38.19 & 37.82 & 27.54 & 27.82 & 27.85 & 26.99 & 36.99 & 36.89 & 36.45 & 36.76 & 26.75 & 26.17 & 26.38 & 26.68 \\
\hline
\end{tabular}


Table.2 Effect of different NPN sources on in vitro utilization of nutrients of TMR, irrespective of niacin level and level of replacement

\begin{tabular}{|c|c|c|c|c|c|}
\hline \multirow[t]{2}{*}{ Parameters } & \multicolumn{3}{|c|}{ Sources } & \multirow[t]{2}{*}{ Control } & \multirow[t]{2}{*}{ SEM } \\
\hline & Uromol & Slow release Urea & Urea & & \\
\hline NGP, ml & $80.63^{a}$ & $80.88^{\mathrm{a}}$ & $84.63^{b}$ & $90.75^{c}$ & 0.87 \\
\hline TDS, mg & 336.58 & 337.31 & 336.90 & 339.27 & 0.55 \\
\hline PF & $3.17^{b}$ & $3.42^{c}$ & $2.97^{\mathrm{a}}$ & $2.99^{\mathrm{a}}$ & 0.04 \\
\hline OMD, \% & $76.01^{\mathrm{a}}$ & $81.98^{\mathrm{c}}$ & $74.53^{\mathrm{a}}$ & $79.96^{\mathrm{b}}$ & 0.61 \\
\hline NDFD, \% & $56.01^{\mathrm{b}}$ & $58.13^{b}$ & $49.49^{a}$ & $52.02^{\mathrm{a}}$ & 0.91 \\
\hline MMP, mg & $159.20^{c}$ & $159.39^{c}$ & $150.72^{b}$ & 139.62 & 1.87 \\
\hline EMMP,\% & $62.24^{c}$ & $57.62^{b}$ & $60.00^{b c}$ & $51.49^{a}$ & 0.83 \\
\hline TD, \% & $76.03^{\mathrm{a}}$ & $81.98^{\mathrm{c}}$ & $74.56^{\mathrm{a}}$ & $79.66^{\mathrm{b}}$ & 0.59 \\
\hline SCFA, mmol & $1.79^{\mathrm{a}}$ & $1.78^{\mathrm{a}}$ & $1.87^{\mathrm{b}}$ & $2.01^{\mathrm{c}}$ & 0.02 \\
\hline pH & $6.32^{\mathrm{a}}$ & $6.63^{b}$ & $6.87^{\mathrm{d}}$ & $6.81^{\mathrm{c}}$ & 0.04 \\
\hline ME,MJ/kg DM & $9.15^{\mathrm{a}}$ & $9.11^{\mathrm{a}}$ & $9.48^{b}$ & $10.51^{\mathrm{c}}$ & 0.084 \\
\hline $\mathrm{NH}_{3}-\mathrm{N}, \mathrm{mg} / \mathrm{dl}$ & $26.59^{d}$ & $23.78^{\mathrm{b}}$ & $25.90^{c}$ & $22.35^{\text {as }}$ & 0.55 \\
\hline Ferm. $\mathrm{CO}_{2}$ & $0.528^{\mathrm{a}}$ & $0.533^{\mathrm{c}}$ & $0.540^{\mathrm{d}}$ & $0.530^{\mathrm{b}}$ & 0.001 \\
\hline Ferm. $\mathrm{CH}_{4}$ & $0.345^{c}$ & $0.346^{\mathrm{d}}$ & $0.337^{\mathrm{a}}$ & $0.341^{\mathrm{b}}$ & 0.001 \\
\hline
\end{tabular}

Means bearing different superscripts in a row differ significantly $(\mathrm{P}<0.05)$

Table.3 Effect of different levels of niacin supplementation on in-vitro utilization of nutrients of TMR, irrespective of NPN sources and level of replacement

\begin{tabular}{|l|c|c|c|c|c|}
\hline Parameters & \multicolumn{4}{|c|}{ Levels of niacin supplementation (ppm) } & SEM \\
\hline NGP, ml & $\mathbf{0}$ & $\mathbf{2 0 0}$ & $\mathbf{4 0 0}$ & $\mathbf{6 0 0}$ & \\
\hline TDS, mg & 83.88 & 84.38 & 85.25 & 83.37 & 0.87 \\
\hline PF & 336.90 & 339.24 & 335.53 & 338.39 & 0.55 \\
\hline OMD, \% & 3.11 & 3.14 & 3.07 & 3.21 & 0.04 \\
\hline NDFD, \% & 77.50 & 78.03 & 77.83 & 79.13 & 0.61 \\
\hline MMP, mg & $51.40^{\mathrm{a}}$ & $53.06^{\mathrm{a}}$ & $54.08^{\mathrm{ab}}$ & $57.11^{\mathrm{b}}$ & 0.91 \\
\hline EMMP, \% & 152.37 & 153.61 & 147.98 & 154.96 & 1.87 \\
\hline TD,\% & 58.42 & 58.12 & 56.74 & 58.07 & 0.83 \\
\hline SCFA, mmol & 77.59 & 77.72 & 77.74 & 79.17 & 0.59 \\
\hline pH & 1.85 & 1.86 & 1.88 & 1.84 & 0.02 \\
\hline ME,MJ/kg DM & 6.66 & 6.66 & 6.67 & 6.63 & 0.04 \\
\hline NH -N mg/dl & $9.45^{\mathbf{3}}$ & 9.46 & 9.59 & 9.39 & 0.08 \\
\hline Ferm.CO & $26.58^{\mathrm{d}}$ & $24.56^{\mathrm{b}}$ & $25.74^{\mathrm{c}}$ & $21.74^{\mathrm{a}}$ & 0.55 \\
\hline Ferm.CH4 & $0.532^{\mathrm{a}}$ & $0.534^{\mathrm{d}}$ & $0.533^{\mathrm{c}}$ & $0.532^{\mathrm{b}}$ & 0.001 \\
\hline
\end{tabular}

Means bearing different superscripts in a row differ significantly $(\mathrm{P}<0.05)$ 
Table.4 Effect of NPN sources on in vitro volatile fatty acids production (mmol/dL) of TMR, irrespective of Niacin supplementation and level of replacement

\begin{tabular}{|l|c|c|c|c|c|}
\hline PARAMIETERS & Urea & Slow release urea & Uromol & Control & SEM \\
\hline Acetic acid & $4.48^{\mathrm{d}}$ & $3.54^{\mathrm{b}}$ & $3.29^{\mathrm{a}}$ & $4.04^{\mathrm{c}}$ & 0.115 \\
\hline Propionic acid & $1.19^{\mathrm{d}}$ & $0.94^{\mathrm{a}}$ & $0.96^{\mathrm{b}}$ & $1.12^{\mathrm{c}}$ & 0.028 \\
\hline Iso butyric acid & $0.046^{\mathrm{c}}$ & $0.037^{\mathrm{b}}$ & $0.036^{\mathrm{a}}$ & $0.047^{\mathrm{d}}$ & 0.001 \\
\hline Butyric acid & $0.577^{\mathrm{d}}$ & $0.486^{\mathrm{a}}$ & $0.516^{\mathrm{b}}$ & $0.563^{\mathrm{c}}$ & 0.013 \\
\hline Iso valeric acid & $0.088^{\mathrm{c}}$ & $0.076^{\mathrm{c}}$ & $0.067^{\mathrm{a}}$ & $0.093^{\mathrm{d}}$ & 0.002 \\
\hline Valeric acid & $0.054^{\mathrm{c}}$ & $0.046^{\mathrm{a}}$ & $0.047^{\mathrm{b}}$ & $0.063^{\mathrm{d}}$ & 0.001 \\
\hline TVFA's & $6.44^{\mathrm{d}}$ & $5.13^{\mathrm{b}}$ & $4.93^{\mathrm{a}}$ & $5.93^{\mathrm{c}}$ & 0.159 \\
\hline Relative proportion, \% & & & & & \\
\hline Acetate & $69.51^{\mathrm{d}}$ & $69.06^{\mathrm{c}}$ & $66.82^{\mathrm{a}}$ & $68.13^{\mathrm{b}}$ & 0.205 \\
\hline Propionate & $18.60^{\mathrm{b}}$ & $18.38^{\mathrm{a}}$ & $19.65^{\mathrm{d}}$ & $18.89^{\mathrm{c}}$ & 0.104 \\
\hline Iso butyrate & $0.712^{\mathrm{a}}$ & $0.715^{\mathrm{b}}$ & $0.734^{\mathrm{b}}$ & $0.804^{\mathrm{c}}$ & 0.007 \\
\hline Butyrate & $8.96^{\mathrm{a}}$ & $9.45^{\mathrm{b}}$ & $10.46^{\mathrm{d}}$ & $9.51^{\mathrm{c}}$ & 0.106 \\
\hline Isovalerate & $1.36^{\mathrm{b}}$ & $1.48^{\mathrm{c}}$ & $1.36^{\mathrm{a}}$ & $1.58^{\mathrm{b}}$ & 0.018 \\
\hline Valerate & $0.845^{\mathrm{a}}$ & $0.889^{\mathrm{b}}$ & $0.961^{\mathrm{c}}$ & $1.06^{\mathrm{d}}$ & 0.016 \\
\hline A:P ratio & $3.73^{\mathrm{c}}$ & $3.75^{\mathrm{d}}$ & $3.40^{\mathrm{a}}$ & $3.60^{\mathrm{b}}$ & 0.029 \\
\hline
\end{tabular}

Means bearing different superscripts in a row differ significantly $(\mathrm{P}<0.05)$

Table.5 Effect of Niacin supplementation on in vitro volatile fatty acids production (mmol/dL) of TMR, irrespective of NPN sources and level of replacement

\begin{tabular}{|c|c|c|c|c|c|}
\hline \multirow[t]{2}{*}{ PARAMETERS } & \multicolumn{4}{|c|}{ Levels of niacin (ppm) } & \multirow[t]{2}{*}{ SEM } \\
\hline & $\mathbf{0}$ & 200 & 400 & 600 & \\
\hline Acetic acid & $3.71^{\mathrm{b}}$ & $4.16^{\mathrm{d}}$ & $3.68^{\mathrm{a}}$ & $3.80^{c}$ & 0.115 \\
\hline Propionic acid & $1.01^{\mathrm{a}}$ & $1.15^{\mathrm{d}}$ & $1.03^{\mathrm{a}}$ & $1.05^{\mathrm{c}}$ & 0.028 \\
\hline Iso butyric acid & $0.041^{\mathrm{c}}$ & $0.046^{\mathrm{d}}$ & $0.039^{\mathrm{a}}$ & $0.040^{\mathrm{b}}$ & 0.001 \\
\hline Butyric acid & $0.512^{\mathrm{b}}$ & $0.593^{d}$ & $0.508^{\mathrm{a}}$ & $0.528^{c}$ & 0.013 \\
\hline Iso valeric acid & $0.077^{\mathrm{b}}$ & $0.089^{d}$ & $0.076^{\mathrm{a}}$ & $0.080^{c}$ & 0.002 \\
\hline Valeric acid & $0.052^{\mathrm{c}}$ & $0.057^{\mathrm{d}}$ & $0.049^{\mathrm{a}}$ & $0.051^{\mathrm{b}}$ & 0.001 \\
\hline TVFA's & $5.41^{b}$ & $6.10^{\mathrm{d}}$ & $5.36^{\mathrm{a}}$ & $5.55 \mathrm{c}$ & 0.159 \\
\hline \multicolumn{6}{|c|}{ Relative proportion, $\%$} \\
\hline Acetate & $68.66^{\mathrm{c}}$ & $68.25^{\mathrm{a}}$ & $68.33^{b}$ & $68.28^{\mathrm{a}}$ & 0.205 \\
\hline Propionate & $18.70^{\mathrm{a}}$ & $18.84^{\mathrm{b}}$ & $18.98^{\mathrm{c}}$ & $19.02^{d}$ & 0.104 \\
\hline Iso butyrate & $0.752^{b}$ & $0.747^{b}$ & $0.733^{\mathrm{a}}$ & $0.732^{\mathrm{a}}$ & 0.007 \\
\hline Butyrate & $9.48^{\mathrm{a}}$ & $9.73^{d}$ & $9.59^{c}$ & $9.57^{b}$ & 0.106 \\
\hline Isovalerate & $1.43^{\mathrm{a}}$ & $1.47^{\mathrm{c}}$ & $1.43^{\mathrm{a}}$ & $1.46^{\mathrm{b}}$ & 0.018 \\
\hline Valerate & $0.955^{\mathrm{d}}$ & $0.943^{c}$ & $0.925^{\mathrm{a}}$ & $0.935^{b}$ & 0.016 \\
\hline A:P ratio & $3.67^{d}$ & $3.62^{c}$ & $3.60^{\mathrm{b}}$ & $3.59^{\mathrm{a}}$ & 0.029 \\
\hline
\end{tabular}

Means bearing different superscripts in a row differ significantly $(\mathrm{P}<0.05)$ 
The propionate percent was statistically higher in uromol $(19.65 \%)$ and lowest in slow release urea based TMR $(18.38 \%)$. The percent isobutyric was significantly higher in control TMR $(0.80 \%)$ whereas it was significantly lower in urea based TMR $(0.71 \%)$. The butyrate percent was observed to be highest in uromol based ration (10.46 $\%)$ followed by control and slow release urea based TMR. and lowest percent in urea based ration $(8.96 \%)$. The acetate to propionate ratio was significantly lowest in uromol (3.40) and highest in slow release urea based TMR (3.75)

The effect of graded levels of niacin supplementation on in vitro volatile fatty acids, irrespective of different NPN source and level of replacement is presented in Table 5. The TVFA concentration $\mathrm{mmol} / \mathrm{dL}$ was significantly lowest at $400 \mathrm{ppm}$ level (5.36 $\mathrm{mmol} / \mathrm{dL}$ ) and highest at $200 \mathrm{ppm}$ level of niacin supplementation in TMR (6.10 $\mathrm{mmol} / \mathrm{dL}$ ). The relative percent of acetate was significantly lowest at $200 \mathrm{ppm}$ and $600 \mathrm{ppm}$ level; however, it was significantly highest at $0 \mathrm{ppm}$ level of niacin. The relative proportion of propionate was significantly lower at 0 ppm and highest at $600 \mathrm{ppm}$ level of niacin supplementation. The percent butyrate was significantly lowest at $0 \mathrm{ppm}$ and highest at $200 \mathrm{ppm}$ level of niacin supplementation. The branched chain fatty acids i.e. iso-valeric was highest at $200 \mathrm{ppm}$ and lowest at $400 \mathrm{ppm}$ and $0 \mathrm{ppm}$ level of niacin supplementation. The A: $\mathrm{P}$ ratio was observed significantly lowest at $600 \mathrm{ppm}$ and highest at $0 \mathrm{ppm}$ level of niacin supplementation (3.67).

It can be concluded that slow release urea seems to be better option than urea and uromol as NPN supplement in the diets of ruminants when high (30\% of total $\mathrm{CP}$ ) urea based TMR is to be prepared. On the basis of higher partition factor, TD\%, OMD\%, but the microbial mass production was significantly comparable in slow release urea and uromol based TMR although the efficiency of microbial mass production was higher in uromol based ration. It can be concluded that slow release urea seems to be better option than urea and uromol as NPN supplement in the diets of ruminants when high $(30 \%$ of total CP) urea based TMR is to be prepared. Supplementation of niacin in high urea based TMR did not have any significant effect on microbial mass production and its efficiency. But the NDFD\% was higher at 600ppm level. The in vitro $\mathrm{NH}_{3}$ concentration was significantly reduced at $600 \mathrm{ppm}$ level of niacin supplementation. The TVFA concentration was significantly higher urea based TMR and lowest in uromol based TMR. Niacin supplementation produced significantly higher TVFA at $200 \mathrm{ppm}$ level and lowest at $400 \mathrm{ppm}$ in TMR.

\section{References}

Campbell, J.M., Murphy, M.R., Christensen, R.A. and Ovetton, T.R. 1994. Kinetics of niacin supplements in lactating dairy cows. J.DairySci., 77: 566-575.

Cottyn, B.G. and Boucque, C.V. 1968. Rapid methods for the gas chromatographic determination of volatile acids in rumen fluid. J. Agri. F. Chem.16: 105-107.

Dreosti, I. E. 1984. Niacin. J. Food Nutr.41: 126-134.

Erickson, P. S., Trusk, A.M. and Murphy, M.R. 1990. Effects of niacin source on epinephrine stimulation of plasma nonesterified fatty acid and glucose concentrations, on diet digestibility and on rumen protozoal numbers in lactating dairy cows. J. Nutr., 120: 1648- 1653.

Makkar, H.P.S. 2004.Recent advances in the in vitro gas method for evaluation of nutritional quality of feed resources. In: Assessing Quality and Safety of Animal Feeds. FAO Animal Production and 
Health Series 160. FAO, Rome, pp. 5588

Menke, K. H., Raab, L., Salewski, A., Steingass, H., Fritz, D and Scheinder, W. 1979. The estimation of the digestibility and metabolizable energy content of ruminant feed stuffs from the gas production when they are incubated with rumen liquor in vitro. J. Agric. Sci. Cambridge, 92: 217-222

Nangia, O. P., Gupta, M., Sindhu, S. and Garg, S. K. 2000. Influence of niacin supplementation on rumen fermentation and microbial protein synthesis in buffaloes. Ind. J. Anim. Sci.70: 764-765.
Riddell, D.O., Bartley, E.E. and Dayton, A. D. 1980.Effect of nicotinic acid on rumen fermentation in vitro and in vivo. J. Dairy Sci., 63(9): 1429-1436.

Riddell, D.O., Bartley, E.E. and Dayton, A.D. 1981. Effect of nicotinic acid on microbial protein synthesis in vitro and on dairy cattle growth and milk production. J. Dairy Sci., 64: 782.

Snedecor, G. W and Cochran, W. G. 1994. Statistical Methods, 11th Edn. The Iowa State University Press, Ames, IA, p. 267.

\section{How to cite this article:}

Tejbeer Singh, J.S. Lamba, R.S. Grewal and Javed, M. 2018. Influence of Graded Levels of Niacin on in vitro Digestibility of Total Mixed Ration with Different Non-Protein Sources. Int.J.Curr.Microbiol.App.Sci. 7(04): 1040-1047. doi: https://doi.org/10.20546/ijcmas.2018.704.114 